УДК 373.2.04.:361.61

DOI:

Людмила Дрожик, кандидат педагогічних наук, доиент кафедри здоров'я людини, реабілітологї та спеціальної психологіі Харківського національного педагогічного університету імені Г.С. Сковороди Ірина Щербак, кандидат педагогічних наук, доиент кафедри здоров'я людини, реабілітологї та спеціальної психологіі Харківського національного педагогічного університету імені Г.С. Сковороди

\title{
ОРГАНІЗАЦІЯ ІНКЛЮЗИВНОГО НАВЧАННЯ ДІТЕЙ З ОСОБЛИВИМИ ОСВІТНІМИ ПОТРЕБАМИ
}

У статті представлено психолого-педагогічні умови організації інклюзивного навчання дітей дошкільного віку з особливими освітніми потребами. Зазначено, щуо соціалізація $і$ розвиток дітей такої категорії в умовах інклюзивного навчання будуть ефективнішими, якщо вихователі будуть дотримуватися таких психолого-педагогічних умов, як створення інклюзивного освітнього середовища і оптимізація міжособистісних відносин у дітей з особливими освітніми потребами в інклюзивних групах закладудошкільної освіти засобами гри.

Ключові слова: діти дошкільного віку; діти з особливими освітніми потребами; інклюзивна освіта; психолого-педагогічні умови; соціалізація дитини.

תim. 8 .

Liudmyla Drozhyk, Ph.D.(Pedagogy), Associate Professor of the Human's Health, Rehabilitology and Special Psychology Department Kharkiv Hryhoriy Skovoroda National Pedagogical University Iryna Shcherbak, Ph.D. (Pedagogy), Associate Professor of the Human's Health, Rehabilitology and Special Psychology Department Kharkiv Hryhoriy Skovoroda National Pedagogical University

\section{ORGANIZATION OF INCLUSIVE EDUCATION FOR CHILDREN WITH SPECIAL EDUCATIONAL NEEDS}

It is noted in the article that inclusive education today can be considered one of the priorities of the state educational policy of Ukraine, which allows children with special educational needs to study together with their healthy peers, which effectively influences the level of their socialization. Psychological and pedagogical conditions for the organization of inclusive education for preschool children with special educational needs are presented. It is established that the socialization and development of preschool children with special educational needs in inclusive education will be more effective if teachers adhere to such psychological and pedagogical conditions as creating an inclusive educational environment and optimizing interpersonal relationships for children with special educational needs in inclusive groups of preschool education by means of games. It is determined that an inclusive educational environment provides a universal design in the field of education, namely the design of environmental subjects, educational programs and services. It is revealed that one of the components of the organization of an inclusive environment is the use of pedagogical technologies that contribute to the individualization of the educational process, which allows to form a psychological climate favorable to the education for children with special educational needs. Emphasis is placed on the implementation of a person-centered approach in the educational process; on the use of differentiated learning, which involves the development of tasks differentiated by the level of complexity and other criteria, which stimulates the desire of children for further educational activities and increases their self-esteem. An atttention is paid to cooperative learning, which allows children with special educational needs to achieve great success in learning. The emphasis is placed on optimizing interpersonal relationships for children with special educational needs in inclusive groups of preschool education through play, because in the processes that take place during most games, children are somehow forced to build communication with each other, which in turn affects the child's socialization.

Keywords: preschool children; children with special educational needs; inclusive education; psychological and pedagogical conditions; child's socialization.

П остановка проблеми. Розробка нових підходів до розвитку дітей 3 обмеженими можливостями здоров'я $\epsilon$ одним з пріоритетних завдань на сучасному етапі реформування освіти. Особливе місце в модернізації системи освіти посідає дошкільна освіта осіб з особливими освітніми потребами, адже, згідно з демократичними соціальними 
перетвореннями і пріоритетами сьогодення, в нашій країні законодавчо визнано право кожної дитини на здобуття освіти незалежно від місця проживання, статі, нації, соціального статусу, психофізичних та інших особливостей, в тому числі і обмежених можливостей здоров'я. Тільки в інклюзивному суспільстві кожен має можливість особистісної самореалізації, незалежно від потреб і обставин, повністю реалізувати свій потенціал, приносити користь суспільству і стати повноцінним його членом.

Аналіз останніх досліджень і публікацій. На даному етапі розвитку спеціальної освіти в Україні та інших країнах світу зростає роль досліджень, спрямованих на пошук ефективних шляхів організації і впровадження інтеграції дітей, які мають особливі освітні потреби (В. Бондар, Т. Волосевець, Е. Данілявічуте, Л. Дереча, В. Засенко, А. Колупаєва, А. Конопльова, С. Литовченко, Л. Лопаніна, М. Малофєєв, С. Миронова, Ю. Найда, Н. Назарова, К. Островська, Т. Сак, В. Синьов, Л. Трофименко В. Феоктістова, Л. Шипіцина, Н. Шматко, та ін.). Однак, незважаючи на актуальність та проведені дослідження, проблема досліджена недостатньо.

Мета статті полягає у пошуку шляхів організації інклюзивного навчання дітей дошкільного віку з особливими освітніми потребами.

Виклад основного матеріалу. Інклюзивна освіта сьогодні може вважатися одним із пріоритетів державної освітньої політики України. Вона дає змогу дітям із особливими освітніми потребами навчатися спільно зі своїми здоровими ровесниками, що ефективно впливає на рівень їх соціалізації.

Інклюзивна освіта - це комплексний процес забезпечення рівного доступу до якісного навчання шляхом організації діяльності в освітніх установах на основі застосування особистісноорієнтованих методів навчання, 3 урахуванням індивідуальних особливостей [5, 27].

Інклюзія передбачає, що дитина з раннього віку перебуває у соціумі, вчиться виживати. У дітей $\epsilon$ можливості для налагодження дружніх стосунків зі здоровими ровесниками й участі у громадському житті. 3 іншого боку, здорові діти, які навчаються 3 першого класу 3 дітьми 3 особливими потребами, в дорослому віці поіншому ставляться до людей $з$ обмеженими фізичними можливостями: вже не $з$ жалістю чи презирством, як до рівних, вчаться природно сприймати і толерантно ставитися до людських відмінностей, налагоджувати й підтримувати дружні стосунки з людьми, які відрізняються від них.
Включення дітей з особливими потребами в масові освітні установи передбачає спеціалізовану корекційну допомогу і психологічну підтримку, завданням яких є контроль за розвитком дитини, успішність їі навчання, надання допомоги у подоланні проблем адаптації в середовищі здорових однолітків [3, 237].

На нашу думку, потрібно створити необхідні умови для повноцінного навчання дітей 3 особливими освітніми потребами у закладах освіти, включаючи підготовку педагогічних працівників, надання індивідуальної підтримки в ході здобуття освіти з урахуванням потреб дитини, нозології захворювання, отриманні та обробці інформації для засвоєння навчальної програми, забезпечити їм державну підтримку; залучення допоміжного персоналу, переобладнання й пристосування дошкільних закладів і приміщень, оснащення необхідним спеціальним обладнанням, організацію перевезень спеціально обладнаними транспортними засобами.

3 іншого боку, завдяки інтеграції відпадає необхідність розробки спеціальних програм соціальної адаптації дітей із порушенням розвитку після закінчення школи, бо соціальна адаптація й інтеграція відбуваються у процесі навчання, під час якого вихованці набувають необхідних для життєдіяльності знань, умінь і навичок.

Отже, соціалізація і розвиток дітей дошкільного віку з особливими освітніми потребами в умовах інклюзивного навчання буде ефективнішим, якщо вихователі будуть дотримуватися таких психолого-педагогічних умов, як створення інклюзивного освітнього середовища та оптимізація міжособистісних відносин у дітей $з$ особливими освітніми потребами в інклюзивних групах закладу дошкільної освіти засобами гри.

Створення інклюзивного освітнього середовища передбачає універсальний дизайн у сфері освіти: предметів навколишнього середовища, освітніх програм і послуг, застосування відповідних допоміжних технологій (технологічні пристрої або програми); наявність спеціалістів, які супроводжують дітей 3 особливими освітніми потребами, спеціально обладнані кабінети: психологічного розвантаження, лікувальної фізкультури, кімнати для логопедичних занять, ресурсна кімната [1].

Одним з компонентів організації інклюзивного середовища $\epsilon$ застосування педагогічних технологій, які сприяють індивідуалізації освітнього процесу. Під час використання певних педагогічних технологій можна формувати психологічний клімат, сприятливий для навчання дітей з особливими освітніми потребами. 
У навчально-виховному процесі потрібно реалізовувати особистісно-орієнтований підхід [8]. Під час занять з дітьми звертати увагу на неповторну індивідуальність кожного, намагатися вводити дитину у різні педагогічні ситуації особистісного вибору, співпереживання гарантованого успіху, спланованої довіри, творчості. У навчанні і вихованні приділяти увагу діалогічним формам взаємодії з дитиною для того, щоб надати її можливість висловити свою думку.

Слід застосовувати диференційоване навчання, розробляти завдання диференційовані за рівнем складності та за іншими критеріями. Розв'язування посильних задач стимулює бажання дітей до подальшої навчальної діяльності і підвищує самооцінку.

Приділяти увагу кооперативному навчанню, що передбачає навчання в малих групах. Перевага надається змішаним групам дітей з особливими освітніми потребами і здорових. Таке навчання дає змогу досягати великих успіхів у навчанні дітей з особливими освітніми потребами. Навчальне спілкування “учень-учень” допомагає формувати навички подолання проблем та вищі функції мислення. Також, працюючи в групі, кожна дитина отримує можливість діяти, виконуючи поставлене навчальне завдання. І обов'язково у процесі такої роботи формуються комунікативні якості, діти вчаться взаємодіяти один $з$ одним, допомагати один одному, відчувати підтримку іншого. Цей підхід сприяє налагодженню позитивних стосунків у дитячому колективі та допомагає виховувати в дітей почуття відповідальності за своїх одногрупників.

Оптимізацію міжособистісних відносин у дітей з особливими освітніми потребами в інклюзивних групах закладу дошкільної освіти можна здійснювати засобами гри.

У дошкільному віці здійснюється накопичення основ людських знань і умінь, психічних якостей і властивостей, необхідних людині для ефективного співіснування в суспільстві надалі. Формування цілісної картини соціального світу в дошкільному віці - це важливий змістовий компонент процесу соціалізації людини. Провідна роль у ньому належить систематичній навчально-виховній діяльності, що націлена на введення дитини у світ того досвіду, який набуло суспільство. Портрет соціального світу формується в дошкільників у навчально-виховному просторі, і зміст виховання повинен сприяти створенню в них його цілісного образу [2].

Дитина має навчитися орієнтуватися в різноманітному, постійно змінюваному світі [7].

Для розв'язання цієї проблеми необхідно зробити акцент на ігровому процесі, позаяк він для дітей дошкільного віку є найбільш природним способом проведення часу, поєднує у собі як розважальну, так і виховну, навчальну складову, виступає інструментом, методом формування навичок міжособистісного спілкування у дітей [4].

Оскільки в процесах, що відбуваються у ході більшості ігор, діти так чи інакше змушені вибудовувати комунікаційні зв'язки один з одним, то можна ствердити, що практично будь-які ігри впливають на формування міжособистісних відносин серед однолітків. В описаному контексті, що стосується відмінностей, слід говорити лише про ступінь впливу і його значимість у процесі розвитку дитини.

Під час гри діти стверджують свої ділові та вольові якості, з радістю переживають успіхи і гірко страждають у разі невдач. У процесі спілкування у дітей з'являються цілі, яких неодмінно слід досягати. Цього вимагають самі умови гри. Навчання дитини відбувається завдяки включенню її у гру, зосередженню на предметах, присутніх в ігровій ситуації, на сюжеті, в якому розігруються дії. Якщо емоційно дитина не готова або не бажає бути уважною до вимог ігрової ситуації, якщо не готова приймати умови гри, вона виганяється однолітками. Потреба у спілкуванні з однолітками, в емоційному заохоченні з їх боку, змушує дитину до цілеспрямованого запам'ятовування і зосередження. Цілеспрямованість, здатність до зусиль волі - необхідні для розвитку особистісних якостей. У цей час закладається досвід як ігрових, так і реальних взаємин, в основу яких вкладається особлива властивість мислення, яке дозволятиме розглядати ситуацію з позиції іншої людини, передбачити ії можливу поведінку, і на цій основі вибудовувати власні дії.

У грі створюються можливості для контролю здійснення комунікативних зв'язків, що позитивно впливає на розвиток рефлексії дошкільнят.

Можна застосовувати ігри на налагодження взаємодії окремих об'єднань дітей, згуртування дитячого колективу; на розвиток вмінь слухати інших, на формування вмінь відкрито виражати свою думку, відчуття, бажання підкреслювати позитивні якості і гідність інших дітей; на розвиток поваги у спілкуванні, звички користуватися ввічливими словами; на розвиток вміння відповідати на запитання співрозмовників, коротко та коректно формулювати відповідь, формувати мовленнєві навички; на зняття тілесних бар'єрів, розвиток вміння досягати мети прийнятними засобами спілкування, розвиток вміння довіряти, допомагати та підтримувати товаришів у спілкуванні; на розвиток комунікативних 
здібностей та вміння розпізнавати мову міміки та жестів; на формування емпатії, терпимого ставлення до однолітків; на розвиток вміння дружити, ділитися відчуттями, переживаннями, настроєм $з$ товаришами; на розвиток у дітей комунікативних та навичок групової роботи.

Висновки і перспективи. Запропоновані психолого-педагогічні умови забезпечать дитині з особливостями психофізичного розвитку підвищення почуття власної гідності, впевненості у собі; ігрові об'єднання мають найбільш значущий вплив на формування комунікативних умінь дитини, а спілкування в них є регулятором “ділової” співпраці дітей, де збагачення ігор комунікативним змістом сприятиме формуванню комунікативних умінь.

\section{ЛІТЕРАТУРА}

1. Антощак О. Інклюзивна освіта : шляхи від теорії до практики. Директор школи. 2016. № 9/ 10. C. $72-78$.

2. Волік Н. До проблеми соціалізації дітей дошкільного віку з вадами мовлення. Науковий вісник Мелітопольського державного педагогічного університету. № 1(18). 2017. С. 26-31.

3. Гевко І. В. Значення інноваційних технологій при здійсненні інклюзивної освіти. Педагогічний альманах: збірник Комунального вищого навчального закладу Херсонська академія неперервної освіти Херсонської обласної ради. Херсон, 2018. Випуск 37. С. 236-240.

4. Гордій Н. М., Корякіна І. В., Дмитренко А. П. Гра як засіб розвитку комунікативної компетентності дітей дошкільного віку. Педагогічні науки : збірник наукових праџь. Вип. LXXXII. Том 3. 2018. C. 91-98.

5. Данілавічютє Е. А. Стратегії викладання в інклюзивному навчальному закладі : навчальнометодичний посібник. Київ, 2012. 287 с.

6. Проценко О., Борисенко Л. Умови забезпечення якості інклюзивної освіти у загальноосвітньому навчальному закладі. Молодь і ринок. Щомісячний науково-педагогічний журнал. Дрогобич, 2015. №11 (130). С. 111-115.

7. Рогальська І. П. Соціалізація особистості у дошкільному дитинстві: сутність, специфіка, супровід: монографія. Київ: Міленіум, 2008. 400 с.

8. Трофименко Л. І. Особистісно-орієнтоване навчання дітей з порушеннями мовлення. Освіта осіб $з$ особливими потребами: иляхи розбудови : зб. наук. пр. Кіровоград, 2014. Вип. 5. C. 82

\section{REFERENCES}

1. Antoshchak, O. (2016). Inkliuzyvna osvita: shliakhy vid teorii do praktyky [Inclusive education: ways from theory to practice]. School Director. No. 9/10. pp. 72-78. [in Ukrainian].

2. Volik, N. (2017). Do problemy sotsializatsii ditei doshkilnoho viku z vadamy movlennia [To the problem of socialization of preschool children with speech defects]. Scientific Bulletin of Melitopol State Pedagogical University. No. 1(18). pp. 26-31.[in Ukrainian].

3. Hevko, I. V. (2018). Znachennia innovatsiinykh tekhnolohii pry zdiisnenni inkliuzyvnoi osvity [The importance of innovative technologies in the implementation of inclusive education]. Pedagogical Almanac: Collection of the Communal Higher Educational Institution Kherson Academy of Continuing Education of the Kherson Regional Council. Kherson. Vol. 37. pp. 236-240. [in Ukrainian].

4. Hordii, N. M., Koriakina, I. V. \& Dmytrenko, A. P. (2018). Hra yak zasib rozvytku komunikatyvnoi kompetentnosti ditei doshkilnoho viku [Play as a means of developing communicative competence for preschool children]. Pedagogical sciences: a collection of scientific works. Issue. LXXXII. Vol. 3. pp. 91-98. [in Ukrainian].

5. Danilavichiutie, E. A. (2012). Stratehii vykladannia v inkliuzyvnomu navchalnomu zakladi : navchalno-metodychnyi posibnyk [Teaching strategies in an inclusive school: a study guide]. Kyiv, 287 p. [in Ukrainian].

6. Protsenko, O., \& Borysenko, L. (2015). Umovy zabezpechennia yakosti inkliuzyvnoi osvity u zahalnoosvitnomu navchalnomu zakladi [Conditions for ensuring the quality of inclusive education in a secondary school]. Youth \& market. Monthly scientific-pedagogical journal Drohobych. No.11 (130). pp. 111-115. [in Ukrainian].

7. Rohalska, I. P. (2008). Sotsializatsiia osobystosti u doshkilnomu dytynstvi: sutnist, spetsyfika, suprovid: monohrafiia [Socialization of personality in preschool childhood: essence, specificity, support: monograph]. Kyiv, 400 p. [in Ukrainian].

8. Trofymenko, L. I. (2014). Osobystisnooriientovane navchannia ditei $\mathrm{z}$ porushenniamy movlennia [Personality-oriented education of children with speech disorders]. Education of persons with special needs: ways of development: coll. science. works. Kirovohrad, Vol. 5. pp. 82-89. [in Ukrainian].

Стаття надійшла до редакції 14.12.2020

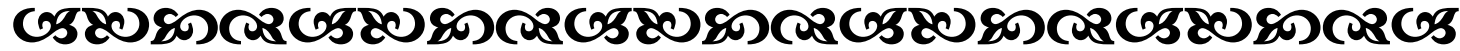

